\title{
IMPACT OF FOREIGN DIRECT INVESTMENT (FDI) ON ECONOMIC GROWTH IN SRI LANKA: 1978-2003
}

\author{
By
}

Jayasundara Mudiyanselage Podimenike Pathirage

Thesis Submitted to the University of Sri Jayawardenepura for the Award of the Degree of Doctor of Philosophy in Economics 2007 
"The work described in this thesis was carried out by me under the supervisors Prof. P. Wilson and Prof. Jagath Wickramasinghe and a report on this has not been submitted in whole or in part to any University or any other Institute for another Degree/Diploma".

\author{
.........Path'ragr....... \\ J. M. P. Pathirage
}


We certify that the above statement made by the candidate is true and that this thesis is suitable for submission to the University for the purpose of evaluation".

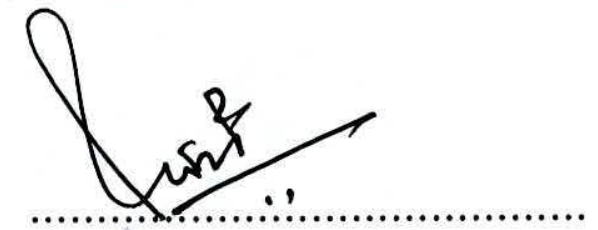

Prof. P. Wilson
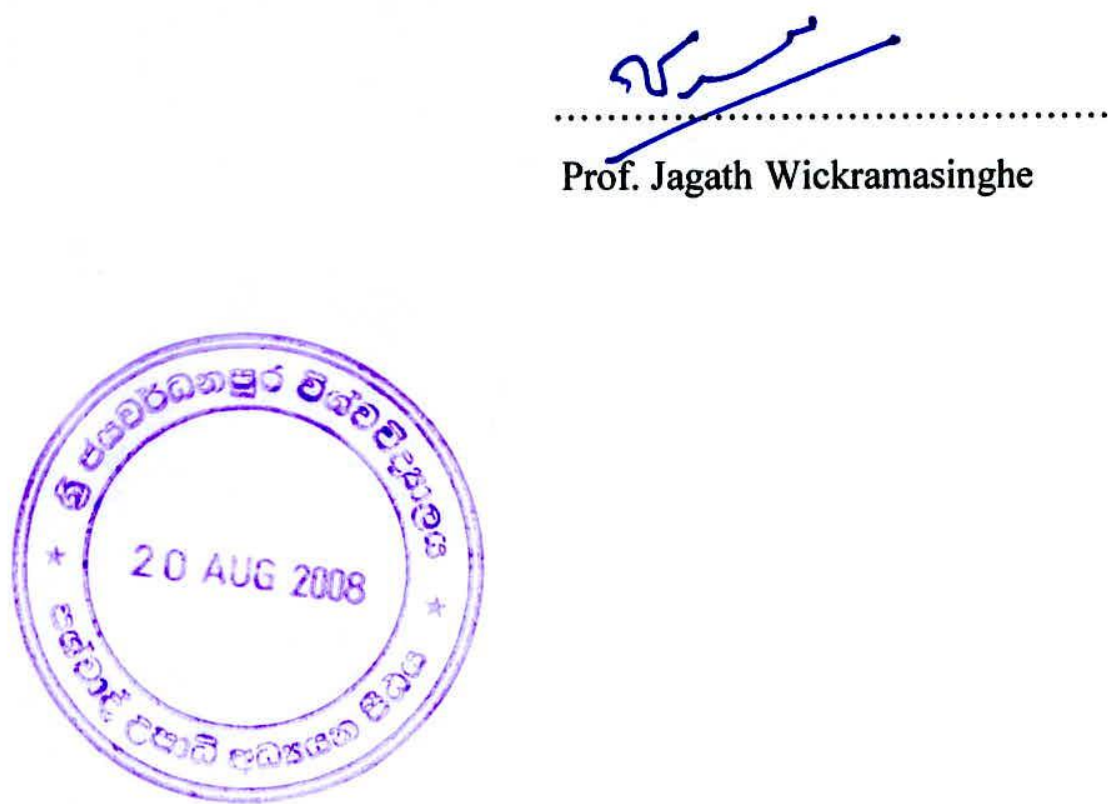


\section{TABLE OF CONTENT}

Page

TABLE OF CONTENT

LIST OF TABLES

LIST OF FIGURES X X

ACKNOWLEDGEMENTS II

$\begin{array}{lll}\text { ABSTRACT } & \text { XIII }\end{array}$

\section{CHAPTER 1: INTRODUCTION}

1.1 Background of the Study 1

1.2 Definition of Foreign Direct Investment 4

1.2.1 FDI and Its Link to Economic Growth and Development 8

1.3 Research Problem and Issues 11

$\begin{array}{ll}\text { 1.3.1 Research Questions } & 15\end{array}$

1.4 The Objectives of the Study 16

$\begin{array}{lll}\text { 1.5 Organization of the Study } & 17\end{array}$

$\begin{array}{lr}\text { Notes on Chapter } 1 & 18\end{array}$

CHAPTER 2: REVIEW OF LITERATURE ON FOREIGN DIRECT INVESTMENT

$\begin{array}{lll}2.1 & \text { Introduction } & 22\end{array}$

2.2 Theories of Foreign Direct Investment 23

2.2.1 Micro Theories: Determinants of FDI 23

2.2.2 Macro Theories: Impact of FDI on Economic Growth 27

2.2.2.1 Proponents of Foreign Direct Investment 28

2.2.2.2 The Dependencia School $\quad 30$

2.2.2.3 The Bargaining Approach 31

2.2.2.4 The Structuralist Approach $\quad 32$ 
2.2.2.6 The Malign Model of FDI 35

2.3 Review of Literature on Specific Studies 36

2.3.1 Increasing the Domestic Investment and Growth 36

2.3.2 Income Distribution $\quad 40$

2.3.3 Technology Transfer 41

2.3.4 Improving the Local Productivity 43

2.3.5 Employment Generation 44

2.3.6 Industrial Development 45

2.3.7 Impact on Export Sector Development 46

2.3.8 Impact on Balance of Payments $\quad 49$

2.4 Empirical Studies: Short-run and Long-run Relationship of FDI and Economic Growth 53

2.5 Studies on FDI in Sri Lanka 59

2.6 Conclusion 63

Notes on Chapter $2 \quad 63$

\section{CHAPTER 3: METHODOLOGY TO THE STUDY}

$\begin{array}{lll}3.1 & \text { Introduction } & 67\end{array}$

3.2 Hypotheses of the Study 68

3.3 Analytical Methods of the Study 69

$\begin{array}{ll}\text { 3.3.1 Qualitative Analyses } & 69\end{array}$

$\begin{array}{ll}\text { 3.3.2 Quantitative Analysis } & 70\end{array}$

3.4 Sources of Information and Data 76

$\begin{array}{lll}3.5 & \text { Limitations of the Study } & 77\end{array}$

$\begin{array}{lll}3.6 & \text { Conclusion } & 79\end{array}$

$\begin{array}{lr}\text { Notes on Chapter } 3 & 80\end{array}$ 
CHAPTER 4: EXTERNAL CAPITAL REQUIREMENTS IN THE PROCESS OF CAPITAL FORMATION

4.1 Introduction

4.2 The Two Gap Approach: As an Early Economic Rational for Foreign Capital

4.3 Importance of FDI as a Source of Capital Formation 89

4.4 Foreign Direct Investment in Developing Countries 93

4.5 The Case of Sri Lanka 100

$\begin{array}{lll}4.6 & \text { Conclusion } & 113\end{array}$

$\begin{array}{lr}\text { Notes on Chapter } 4 & 115\end{array}$

CHAPTER 5: POLICY ENVIRONMENT FOR ATTRACTING FDI IN SRI LANKA

5.1 Introduction

5.2 The Economic Attractiveness of a Country for FDI 119

5.3 Policy Environment in Sri Lanka for FDI Attraction 120

$\begin{array}{ll}\text { 5.3.1 Trade Policy and Tariff Reforms } & 121\end{array}$

$\begin{array}{ll}\text { 5.3.2 Export Development Strategy } & 129\end{array}$

$\begin{array}{ll}\text { 5.3.3 Investment Climate with FDI Policy } & 130\end{array}$

5.3.3.1 The Board of Investment (BOI) 133

5.3.4 Investment Climate with other Macro Economics

Policies

5.4 Infrastructure Facilities for Attracting FDI 135

5.5 Trends and Patterns of FDI in Sri Lanka 137

5.6 Distribution of FDI by Sector, Origin and Geographical

Location

5.6.1 Distribution of FDI By Sector $\quad 143$

$\begin{array}{ll}\text { 5.6.2 Origin of FDI } & 146\end{array}$

$\begin{array}{lll}5.7 & \text { Conclusion } & 154\end{array}$

$\begin{array}{ll}\text { Notes on Chapter } 5 & 155\end{array}$ 


\subsection{Introduction}

\section{PART 1: IMPACT OF FDI ON MANUFACTURING EXPORT DEVELOPMENT IN SRI LANKA}

\subsection{GDP Composition and Structural Changes in Sri Lanka}

6.2.1 Manufacturing Performance in Sri Lanka

6.2.2 Changing Pattern of Manufacturing Sector

6.3 FDI and Manufacturing Export Expansion in Sri Lanka

6.3.1 Significance of the Export Sector

6.3.2 Manufacturing Exports in Sri Lanka

6.3.3 FDI and Manufacturing Exports in Sri Lanka

6.3.4 Role of FDI in Manufacturing Exports in Sri Lanka

6.3.5 Contribution of BOI Projects to Domestic Value Added

6.3.6 Impact of FDI on Balance of Payments (BOP) in Sri Lanka

6.3.6.1 Direct Effects on BOP

\section{PART 11: IMPACT OF FDI ON EMPLOYMENT GENERATION IN SRI LANKA}

6.4 Significance of Employment Generation in a Country 209

6.5 FDI and Its Link to Employment Generation 209

6.5.1 Direct Employment Effects of FDI 211

6.5.1.1 Labour Productivity in the Manufacturing Sector 223

6.5.1.2 Employment in Export Processing Zones (EPZs) 225

6.5.2 Indirect Employment Effects of FDI 228

6.5.3 Technology and Skill Transfer 230

6.6 Conclusion 232

Notes on Chapter $6 \quad 233$ 
CHAPTER 7: IMPACT OF FDI ON ECONOMIC GROWTH IN SRI LANKA (AN EMPIRICAL MODEL)

$\begin{array}{lll}7.1 & \text { Introduction } & 236\end{array}$

$\begin{array}{lll}7.2 & \text { Analytical Framework } & 237\end{array}$

$\begin{array}{ll}\text { 7.2.1 The Model and the Variables } & 237\end{array}$

$\begin{array}{ll}\text { 7.3 Methodology Adopted for Estimation } & 239\end{array}$

7.3.1 Unit Root Tests 240

7.3.2 Augmented Dickey Fuller (ADF) Test 241

$\begin{array}{ll}\text { 7.3.3 Cointegration Tests } & 242\end{array}$

7.3.4 Vector Error Correction Model (VECM) 244

7.4 Econometric Results 246

7.5 Causal Relationship between the Variables (GDP, FDI, DIN and $\begin{array}{ll}\text { EX) } & 257\end{array}$

7.5.1 The Granger Causality Test 257

$\begin{array}{lll}7.6 \text { Conclusion } & 264\end{array}$

$\begin{array}{ll}\text { Notes on Chapter } 7 & 265\end{array}$

\section{CHAPTER 8: SUMMARY AND CONCLUSIONS}

$\begin{array}{lll}8.1 & \text { Introduction } & 268\end{array}$

$\begin{array}{lll}\text { 8.2 Summary of the Chapters } & 269\end{array}$

8.3 Policy Implications of the Study 274

8.3.1 Attracting more FDI into the Country with Appropriate Policy $\begin{array}{ll}\text { Changes } & 274\end{array}$

8.3.2 Sustainability in the Garment and Apparel Sector 276

8.3.3 Improving the Value Addition in the Apparel Sector 276

$\begin{array}{ll}\text { 8.3.4 Product Diversification } & 277\end{array}$

8.3.5 Improving the Dignity and the Image of the Factory Workers 277

8.3.6 Facing the Emerging Global Market Competition 278

8.3.7 Maintaining the Economic and Political Stability 279

8.3.8 Expansion of the Manufacturing Sector to Remote Areas 280

8.4 Areas for Further Research 280 
BIBLIOGRAPHY

APPENDICES

Appendix 1: Variables and Real Data used for Time Series Data

Analysis: 1978-2005

Appendix 2: Real Quarterly Data: 1978-2005

Appendix 3: Descriptive Statistics for 1978-2005

326

Appendix 4: Unit-root tests for 1980 to 2005

328

Appendix 5: Cointegration Analysis

335

Appendix 6: Error Correction Model

336

Appendix 7: Granger Causality Tests 


\section{LIST OF TABLES}

Table 1.1 Net Private Capital Flows to Developing Countries:1996-2003 3

Table 1.2 Incremental Capital Output Ratio (ICOR) in Sri Lanka: 1961-2004 14

Table 4.1 External Debt, Debt Service Payments and Official Flows to Developing Countries:1991-2003 91

Table 4.2 Inflows of FDI to Developing Countries by Region: 1992-2003 94

Table 4.3 Inflows of FDI to East and South-East Asia: 1992-2003 97

Table 4.4 Inflows of FDI to South Asia: 1992-2003 99

Table 4.5 Real GDP Growth Rates of South Asian Countries: 1998-2002 101

Table 4.6 Investment-Savings (Domestic savings) Gap in Sri Lanka : 19782003

Table 4.7 Government Revenue, Expenditure and Budget Deficit/Surplus in $\begin{array}{ll}\text { Sri Lanka: 1978-2003 } & 104\end{array}$

Table 4.8 Exports, Imports and Exports-Imports Gap in Sri Lanka: 1978-2003 106

Table 4.9 Investment-Savings (National Savings) Gap in Sri Lanka: 19782003

Table 4.10 External Resource Gap and Source of Financing: 1981-2003 108

Table 4.11 External Debt and Debt Service Payments: 1978-2003 111

Table 4.12 FDI Inflows as a Percentage of Investment-Savings Gap: 1978-2003 112

Table 5.1 Import Duty and the Share of Dutiable Imports: 1978-2003 125

Table 5.2 Contribution of Export Duties to Government Revenue: 1978-1993 127

Table 5.3 Major Tariff Reforms in Sri Lanka: 1977-2002 128

Table 5.4 Profile of Privatizations with Major Foreign Investment: 1989-2003 138

Table 5.5 Inflows of FDI to Sri Lanka: 1978-2003 140

Table 5.6 Comparative FDI Performance of Sri Lanka: 1981-2002 143

Table 5.7 Sectoral Distribution of Cumulative FDI Flows: 1979-2004 144

Table 5.8 Cumulative FDI Flows among the Sectors and Sub Sectors in Manufacturing, as at end 2004

Table 5.9 Home Country Distribution of FDI in Sri Lanka, Cumulative, 19792003 
Table 5.11 Distribution of FDI in Operation by Districts, Cumulative as at end 2002

Table 5.12 No. of Projects and Estimated Investment by Location-2004

Table 6.1 Percentage Distribution of GDP by Sectors: 1978-2003

Table 6.2 Percentage of Capacity Utilization and Contribution of the Manufacturing Sector to GDP: 1978-2003

Table 6.3 Percentage Distribution of Manufacturing Sector (by Sub-sectors) in Sri Lanka: 1978-2003

Table 6.4 Percentage Distribution of Value Added in the Manufacturing Sector (by Sub-sectors) in Developing Countries: 1990 and 2001

Table 6.5 Manufacturing Exports in Selected South, East and South-East Asian Countries in 1990 and 2000

Table 6.6 Inflow of FDI in the Manufacturing Sector (by Sub Sectors) 1979, 1985, 1991, 1997 and 2004

Table 6.7 Manufacturing Exports as a Percentage of Manufacturing Output :1978-2003

Table 6.8 Manufacturing Exports as a Percentage of Total Merchandise Exports:1978-2003

Table 6.9 Manufacturing Exports in Selected Developing Economies: 1980-2000

Table 6.10 Percentage Distribution of Exports in Sri Lanka by Sectors: 1977, 1993 and 2003

Table 6.11 Exports Performance of BOI Projects in Sri Lanka:1979-2003

Table 6.12 Exports of Foreign Firms as a Percentage of Total Merchandise Exports:1979-2003

Table 6.13 Percentage Distribution of Industrial Exports in Sri Lanka by Sub Sectors (For Some Selected Years)

Table 6.14 Export Earnings of BOI Projects by Sectors as at end 2004

Table 6.15 Manufacturing Exports by Foreign Firms by Sectors (100\% Foreign Owned and Joint Ventures) for Some Selected Years: 1979, 1985, 1991, 1997, 2002 and 2004

Table 6.16 Domestic Value Added of BOI Projects:1979-2003 
Table 6.17 Direct Effects of FDI on the Balance of Payments of Sri Lanka: 1979-2003 206

Table 6.18 Unemployment Rates in Sri Lanka: 1978-2003 212

Table 6.19 Share of Employment in Industrial and Manufacturing Sectors in Sri Lanka: 1978-2003 215

Table 6.20 Share of Manufacturing Employment by Region: 1990 and $2000 \quad 218$

Table 6.21 Employment in the Manufacturing Sector of BOI Projects in Sri Lanka:1978-2003

Table 6.22 Total (Cumulative) Employment in BOI Projects by Sectors: 1979, 1985, 1991, 1997, 2002 and 2004.

Table 6. 23 Labour Productivity in the Manufacturing Sector in Sri Lanka: 1978/79-2000

Table 6.24 Employment of Export Processing Zones in Sri Lanka (As at end Dec. 2004)

Table 7.1 Summary of Descriptive Statistics of the data used for Cointegration Analysis: 1978-2005

Table 7.2 (a) Unit Root Tests for 1980 to 2005 - Level

(b) Unit Root Tests for 1981 to 2005 - First difference

Table 7.3 Test of Cointegration among the Variables

Table 7.4 Error Correction Model Representation 255

$\begin{array}{lll}\text { Table } 7.5 \text { Granger Causality Test } & 260\end{array}$

\section{LIST OF CHARTS AND MAPS}

$\begin{array}{lll}\text { Chart 3.1 Overall Methodology of the Research } & 75\end{array}$

Map I Location of Free Trade Zones and Industrial Parks in Sri Lanka 


\section{LIST OF FIGURES}

Figure 4.1 Economic Growth Under the Foreign Exchange Constraint 88

Figure 4.2 Source of Financing the External Resources Gap: 1981-2003 110

Figure 4.3 FDI Inflows as a Percentage of Investment-Savings Gap: 1978-2003

Figure 5.1 Trends in Foreign Direct Investment: 1978-2003 141

Figure 5.2 FDI as a Percentage of Gross Domestic Capital Formation: 1978$2003 \quad 142$

Figure 6.1 Sectoral Composition of GDP in Sri Lanka: 1978 and 2003

Figure 6.2 Manufacturing Exports as a Percentage of Manufacturing Output:1978-2003

Figure 6.3 Manufacturing Exports as a Percentage of Total Merchandise Exports:1978-2003

Figure 6. 4 Percentage Distribution of Exports in Sri Lanka by Sectors: 1977, 1993 and 2003

Figure 6. 5 Exports Performance of BOI Projects in Sri Lanka:1979-2003

Figure 6.6 Exports of Foreign Firms as a Percentage of Total Merchandise Exports:1979-2003

Figure6.7 Percentage Distribution of Industrial Exports by Sub Sectors: 1978 and 2003

Figure 6.8 Domestic Value Added of BOI Projects in Sri Lanka:1978-2003

Figure 6.9 Direct Effects of FDI on the BOP of Sri Lanka:1979-2003

Figure 6.10 Unemployment Rates in Sri Lanka:1978-2003

Figure 6.11 Share of Employment in the Industrial and Manufacturing Sectors in Sri Lanka: 1978-2003

Figure 6.12 Employment in the Manufacturing Sector of BOI

Projects:1978-2003

Figure 7.1 Trend of the Variables(a, b, c, d) 


\section{ACKNOWLEDGEMENTS}

It is my pleasure to express my great gratitude and appreciation to my supervisors Professor P. Wilson and Professor Jagath Wikramasinghe, University of Sri Jayawardenepura, Sri Lanka for their continued encouragement, valuable guidance and patience given to me during the preparation of this thesis. I have greatly benefited from the opportunity to learn under their supervision. My special thanks also go to late Professor W. A. Jayatissa, University of Sri Jayawardenepura, Sri Lanka for his valuable comments and suggestions. I also appreciate the kind assistance given to me by Senior Lecture, Mr Wasantha Athukorala, (PhD student of Queensland University of Technology, Australia), University of Peradeniya, Sri Lanka especially with regard to econometric work.

I wish to express my sincere thanks to Head of the Department, Senior Lecturer Mr Chandra Kumara and other members of the Department of Economics and Faculty of Postgraduate Studies, the University of Sri Jayewardenepura, Sri Lanka for giving me an opportunity and providing facilities to undertake this study.

My thanks are due especially to late Professor Kamal Karunanayake for his valuable comments and supports. I am also grateful to late Professor Sirisena Tilakaratne, Mrs Mangalika Thanthirigama and Professor K. Dharmasena. My appreciation is also should go to my colleagues: Professor Herath Madana Bandara, Senior Lecturer, Dr Mrs K.U.A. Tennakoon, Senior Lecturer, Dr Mrs Ranitha Ratnayake, and Lecturer, Mrs Lakdini Seneviratna, University of Kelaniya, Sri lanka and also Mr Nalaka Gamage, Mrs Manjula Tennakoon, Mr R. B. Tennakoon Mr A. Samitha for their continued encouragement and valuable cooperation during the period of this study.

My thanks are also due to external examiners Professor, D. Atapattu, University of Ruhuna, Sri Lanka and Professor, S. M. P. Senanayake, University of Colombo, Sri Lanka for their valuable comments on the original draft of the thesis. 
Finally, I should also pay my affectionate gratitude to my husband Pathi, two sons Chandana, Supun and daughter Dilini for the continuous encouragement and support they extended to me with dedication and helping me to devote time for the research work without interruption. 


\title{
IMPACT OF FOREIGN DIRECT INVESTMENT (FDI) ON \\ ECONOMIC GROWTH IN SRI LANKA: 1978-2003
}

\author{
Jayasundara Mudiyanselage Podimenike Pathirage
}

\begin{abstract}
Foreign Direct Investment (FDI) has been recognized as a major source of promoting economic growth and development with its package of tangible and intangible assets such as capital, technology, knowledge, managerial skills and market access to developing countries. The deficiency of capital due to the saving-investment and import-export gaps has been considered as a major constraint to economic growth in Sri Lanka. FDI has been an important source of foreign financing to fill these two gaps and overcome the problem of capital formation since 1977. The study is based on time series data mainly from Central Bank of Sri Lanka and Board of Investment (BOI) covering the period of 1978-2003. The prime objective of this study is to analyze the impact of FDI on export-led manufacturing development and its contribution to employment generation in the economy. Both qualitative and quantitative approaches have been used to analyze these impacts of FDI. The production function approach has been utilized as the theoretical framework for undertaking empirical work to test the relationship between FDI and economic growth along with other two variables domestic investment and exports. In this empirical investigation unit root test, cointegration analysis, error correction modeling approaches and causality test have been utilized. The overall results indicated that there was no short-run impact of FDI on GDP growth in Sri Lanka, but the long-run relationship could be recognized. The econometric results further show that FDI alone does not exert an independent influence on economic growth but with the combined effects of domestic investment and exports have made a significant contribution to economic growth.
\end{abstract}


According to the causality test, the direction of causation is not towards from FDI to GDP growth but the direction goes from GDP growth to FDI. Among measures proposed in this connection is sound investment and financial polices to promote diversified FDI that needs to be well coordinated within the macro-economic policy framework, and the need for consistency, and firm commitment to such policies. 